\title{
"Children's Week" as one of the activities of the Polish Childcare Committee in the Second Polish Republic
}

\begin{abstract}
The aim of this article is to discuss "the Children's Week" event organised from 1926 by the Polish Childcare Committee, which was the prototype of today's Children's Day and Mother's Day. This issue has not been the subject of scientific analysis. The aim, meaning and course of "the Children's Week" in the Second Republic of Poland were analysed based on the interwar sources' materials. This holiday was one of the social events organised by the Polish Childcare Committee, which, as a body of the Ministry of Labour and Social Care, was responsible for improving health and social conditions of children and teenagers. Therefore, it organised care units for mothers and children, published scientific papers, propagated tasks related to the care of children and teenagers, and organised and conducted exemplary care institutions. "The Children's Week" was a social event, which aim was to make Poles more interested in the situation of children and teenagers. For seven days the importance of proper care of the youngest children in a rebuilding country was emphasised. Every day was devoted to education or upbringing issues as well as the functioning of schools and social centres. The Children's Day was on the first day of the event, and the Mother's Day on the last. "The Children's Week" in the Second Republic of Poland proceeded in accordance with the programme prepared by the Polish Childcare Committee. Each Voivodeship office tailored the programme to their capabilities and regional conditions. Despite the criticism it attracted, "the Children's Week" was an extremely important social event, which was supported by pedagogical authorities, among others, Janusz Korczak. Annually, the public attention was focused on childcarerelated issues for seven days. This event was in line with the European trends at that time, in which children's rights and freedoms were gaining more and more supporters.
\end{abstract}

Keywords: Second Polish Republic, Children's Week, Polish Childcare Committee, American Relief Administration, celebration, social events

* This text is a product of the research started in 2012 by Urszula Wróblewska, PhD, regarding the activity of the Polish Childcare Committee in the Second Polish Republic. 


\section{Introduction}

Each year, the Children's Day, which was initiated by the United Nations in 1954, is celebrated around the world. This holiday was established as a result of the need and willingness to draw special attention of the European society to the children's situation and rights written down in the United Nations Charter, in 1945, which had been commonly violated during the Second World War. Despite the fact that 20 November was officially declared as the Universal Children's Day, in different countries it is celebrated on different dates and commemorates events important for a given society. In France, children celebrate their holiday on 6 January within the Family's Holiday and in Japan on 5 May, in Paraguay on 16 August, on the anniversary of the Triple Alliance War in 1869, and in Turkey the Children's Day is celebrated together with the Independence Day on 23 April. Whereas in Poland, as in other countries of the former socialist block, as of 1950 the Children's Day is celebrated on 1 June, which is related with the action of collecting signatures under the Stockholm Appeal ${ }^{1}$. However, on the grounds of source materials from the interwar period it can be stated that the origins of the celebrations related with the Children's Day go back to the Second Republic of Poland, where as of 1926 the Polish Childcare Committee had organised the "Children's Week" constituting a prototype of contemporary celebrations organised for the youngest.

The aim of this article is to present the aim of the "Children's Week", its course and meaning in the interwar Poland. Until now, this issue has not constituted a subject of a broader research interest ${ }^{2}$, despite the fact that it constitutes an example of all-Poland celebration raising awareness of the condition and needs of childcare of that time and, at the same time, is a model of social initiative, which indicates changes and new tendencies in the approach to a child in Poland, in the second decade of the $20^{\text {th }}$ century. In this text source materials in the form of pre-war press, archive publications and documents were used. Contents included in the Articles of the Polish Childcare Committee (Statut Polskiego Komitetu Opieki nad Dzieckiem)³, which was the main initiator and propaga-

${ }^{1}$ E.J. OSMAŃCZYK, Encyclopaedia of the United Nations and international relations (Encyklopedia ONZ i stosunków międzynarodowych), Warsaw 1982, p. 45.

2 As a result of the research regarding "the Children's Week" initiated by U. Wróblewska, as of 2012 the Podlasie Museum in Białystok (Muzeum Podlaskie w Białymstoku) together with other cultural institutions has been organising "Children's Week in Białystok" (“Tydzień Dziecka w Białymstoku”) in October. With regard to "the Children's Week" in the context of forgotten, yet, contemporarily inspiring pedagogical initiatives see U.WRÓBLEWSKA, Children's Week? - Korczakinspirationstoday (Tydzień Dziecka?-inspiracjekorczakowskie dzisiaj), A. KORZENIECKA - BONDAR, B. TOŁWIŃSKA, U. WRÓBLEWSKA (ed.), Worlds of everyday life of educational interactions' participants Explorations - Analyses - Interpretations, Scientific Bulletins the Forum of Young Pedagogues (Światy życia codziennego uczestników interakcji wychowawczych Eksploracje - Analizy - Interpretacje, Zeszyty naukowe Forum Młodych Pedagogów), 2012 bulletin no. 17, pp. 223-232; idem, "Children's Week" - Korczak's idea in interwar Biatystok" ("Tydzień Dziecka" - idea korczakowska w międzywojennym Białymstoku), [in:] E.J. KRYŃSKA, A. SUPLICKA, U. WRÓBLEWSKA, (ed.), A child in history - Korczak thread (Dziecko w historii - wątek korczakowski), Białystok 2013, pp. 279-291.

3 The Articles of the Polish Childcare Committee (Statut Polskiego Komitetu Opieki nad Dzieckiem), Warsaw 1926-1928. 
tor of the discussed "Children's Week", had a cognitive value. The information regarding the aim and organisation of the "Children's Week" is included in the publications popularised by the Polish Childcare Committee, among others: in the organisation instructions ${ }^{4}$ issued in 1928, as well as in the magazine "Childcare" ("Opieka nad Dzieckiem") constituting a press body of the Committee ${ }^{5}$. Furthermore, museum resources from the Podlasie Museum in Bialystok (Podlaskie Muzeum w Białymstoku) (hereinafter referred to as the $\mathrm{MBH})$ and source materials deposited in the Lithuanian Central State Archive in Vilnius (hereinafter referred to as the LCSA), where reporting and financial documents regarding the Children's Day organised in Vilnius are stored, were also used.

\section{Forms of the Polish Childcare Committee's activity}

During peace conference in Paris, in 1919, which the principal aim was to stabilise relations with Germany, the Polish issue was also discussed. It happened due to the United States of America's resignation from the isolation strategy and starting a new economic policy towards European countries. This change was based on the belief that in the situation at that time, after the end of the First World War, in order to maintain peace it would be more effective to provide economic measures rather than conduct political activity aimed at maintaining peace. As a result, American financial specialists and advisors were delegated to the Second Republic of Poland ${ }^{6}$.

On 19 February 1919 the American Relief Administration (hereinafter referred to as ARA) was appointed, in Poland known as the American Rescue Department (Amerykański Wydział Ratunkowy) or American Aid Administration (Amerykańska Administracja Pomocy). It has been operating under the patronage and management of the American politician and later also the President of the United States of America in the years 1929-1933,

\footnotetext{
${ }^{4}$ Children's Week. Organisational instructions (Tydzień Dziecka. Instrukcje organizacyjne), Warsaw 1928.

${ }^{5}$ In the interwar period the monthly magazine issued by the Polish Childcare Committee changed its title three times. In the years 1923 - 1931 it was issued by the Hygiene and Medical Department of the PolishAmerican Childcare Committee (Wydział Higieniczno-Lekarski Polsko-Amerykańskiego Komitetu Opieki nad Dzieckiem) under the title: "Childcare. A magazine devoted to the protection of motherhood, taking care of children and youth" ("Opieka nad Dzieckiem. Czasopismo poświęcone ochronie macierzyństwa, opiece nad dziećmi i młodzieżą"); then, between 1932 and 1937 the Polish Childcare Committee was the issuer and issued the magazine under the title: "Child's life. A magazine devoted to the protection of motherhood, taking care of children and youth” (“Życie Dziecka. Czasopismo poświęcone ochronie macierzyństwa, opiece nad dziećmi i młodzieżą"); whereas, as of 1938, two last pre-war issues were entitled: "Youth’s life. A magazine devoted to the protection of motherhood, taking care of children and youth” (“Życie Młodych. Czasopismo poświęcone ochronie macierzyństwa, opiece nad dziećmi i młodzieżą").

${ }^{6}$ G. RYBARCZYK, American aid to Polish children post $1^{\text {st }}$ world war and other forms of aid in the years 1919-1923 (Amerykańska pomoc dla dzieci polskich po I wojnie światowej oraz inne formy pomocy w latach 1919-1923), The Bulletin of library and cultural information (Biuletyn informacji bibliotecznych i kulturalnych) 2005, no. 1 , p. 3 .
} 
Herbert Clark Hoover ${ }^{7}$. The activity of the American Aid Administration (Amerykańska Administracja Pomocy) was supported by the government of Ignacy Paderewski. On 30 March 1919, as a result of joining forces of the Polish government's aid action and the American Mission, the General Relief Committee for Children (Centralny Komitet Pomocy Dzieciom) (hereinafter referred to as GRCC) was established, which was led by the Prime Minister's and compositor's wife - Helena Paderewska ${ }^{8}$.

The GRCC's main tasks included, among others: distribution of medicines, clothes, food as well as various other goods from donations made by the Americans and partly coming from the Polish government subventions, the Polish Emigration and the ARA. In June 1919, the General Relief Committee for Children (Centralny Komitet Pomocy Dzieciom) was renamed to the Polish Relief Committee for Children (Polski Komitet Pomocy Dzieciom (hereinafter referred to as the PRCC) ${ }^{9}$.

In 1920, the Polish-American Relief Committee for Children (Polsko-Amerykański Komitet Pomocy Dzieciom) (hereinafter referred to as the ARCC), which had been appointed in order to reinforce the large humanitarian action of supplementary alimentation for children in Poland initiated by the American society, as well as to reinforce the friendship established as a result of the cooperation between Poland and America ${ }^{10}$, joined the aid action aimed at providing supplementary alimentation for Polish children.

The ARCC's activity continued to be tightly related with the activities undertaken by the American Mission. It resulted from the willingness to prepare the Committee to function independently and conduct aid actions after the H. C. Hoover's mission's withdrawal from Poland ${ }^{11}$. Independence was gained at the beginning of 1926, after withdrawal from this Foundation of the American society's representatives, on 25 January 1926, pursuant to Article 11 of the Decree of 7 February 1919 on foundations and approving donations and legacies (Journal of Rights of the Polish State (Dziennik Praw Państwa Polskiego) No. 15, item 215) the Minister of Labour and Social Care gave the Articles to the said Foundation and named it as the Polish Relief Committee for Children (Polski Komitet Pomocy Dzieciom) ${ }^{12}$. Two years later, on 3 March 1928 the Minister of Labour and Social Care amended the Articles of the Polish Relief Committee for Children (Statut Polskiego Komitetu Pomocy Dzieciom) upon taking into consideration of which the Foundation received new Articles, and under the first article of which its name was changed to the Polish Childcare Committee (hereinafter referred as the PCC or the Committee) ${ }^{13}$.

\footnotetext{
7 Ibidem, pp. 2-4.

${ }^{8}$ G. RYBARCZYK, American aid... (Amerykańska pomoc...), p. 5.

${ }^{9}$ Ibidem, p. 5.

10 The Articles of the Polish... (Statut Polskiego...), p. 1.

11 G. RYBARCZYK, American aid... (Amerykańska pomoc...), pp. 5-6.

12 The Articles of the Polish... (Statut Polskiego...), p. 1.

13 Ibidem, p. 5.
} 
The Polish Childcare Committee performed activities ordered by the Ministry of Labour and Social Care, the PCC's authority comprised of the foundation's council, the executive committee and the audit committee ${ }^{14}$. The activity of the Committee met society's needs resulting from difficult financial, social and cultural situation caused by the First World War. The main aim of the PCC's activity was to: improve the moral, cultural and health condition of children and youth as well as the health and living conditions of infants and pregnant and breastfeeding women irrespectively of denomination and nationality $^{15}$. In order to execute its statutory tasks the Committee issued theses, popularised tasks in the scope of care for children and youth and organised and conducted model care institutions ${ }^{16}$.

The Polish Childcare Committee was engaged in various forms of activity popularised in the territory of whole Poland, among which we can distinguish, for instance: conducting and establishing Stations of Care for the Mother and the Child (Stacje Opieki nad Matką i Dzieckiem). The main aim of the aforementioned stations was to fight against the high infant mortality rate which was influenced by the bad hygienic conditions and a low level of mother's education regarding infants' nutrition and care. While organising Stations the Committee's assumption was that in this fight it is the most important to obtain our natural and powerful ally, that is the habit of breastfeeding. It is necessary to instruct mothers how to breastfeed, when and with what to supplement nutrition and how to cease breastfeeding, how to bath and swaddle a child; in short, to establish simple and healthy rules for taking care of infants, distribute them in oral and written form, always and anywhere, anytime the occasion occurs ${ }^{17}$. Furthermore, the Committee conducted advice offices for mothers and provided them with coupons so that they could exchange them for cash or collect milk distributed under the action called A Drop of Milk (Kropla mleka) ${ }^{18}$.

The Committee organised a system of care for pregnant women, particularly those in the last months of pregnancy. With numerous publications in daily press, organising lectures and talks, mothers-to-be were educated about the impact of their psychological and physical condition on the child's health. Attempts were made to protect pregnant women against performing heavy physical work in conditions adverse for health. Furthermore, poor and single women were taken care of, they were directed to relevant institutions, where they were provided with aid and support ${ }^{19}$.

14 Ibidem, pp. 2-5.

15 Article 4, the Articles of the Polish... (Statut Polskiego...), p. 2.

16 Ibidem, p. 2.

17 T. KOPEĆ, Station of Care for the Mother and the Child (Stacja Opieki nad Matka i Dzieckiem), in the series: "Issues regarding care for the motherhood, children and youth in Poland" ("Zagadnienia opieki nad macierzyństwem, dziećmi i młodzieża w Polsce”), Warsaw 1932, p. 19.

18 Ibidem, p. 18.

19 Ibidem, p. 21. 
Another area of the PCC's activity comprised measures related with prevention of childhood diseases, which at that time were of an epidemiological character. It was ensured that each child was vaccinated against scarlet fever, smallpox and diphtheria at a proper time. Those vaccinations were performed in agreement with local health centres, and a mother and a child were directed to relevant social institutions ${ }^{20}$. Furthermore, in order to improve the health condition as well as to join physical, hygienic and cultural education of children and youth, the Committee organised summer camps for them ${ }^{21}$. The scope of the Polish Childcare Committee's activity also included issues related with the organisation of nurseries, pedagogical advice offices and hygienic and medical care in schools; preschool education; pedagogical support for children disabled at an intellectual and physical level, as well as attention was paid to the situation of educationally neglected children, orphans and juvenile delinquents.

Apart from direct forms of providing aid to persons who needed support, the Committee conducted a wide propaganda action aimed at educating the society about problems with regard to the social care and engaging Poles in activities organised by the PCC. All of the enumerated fundamental aims and forms of activity of the Polish Childcare Committee were popularised during an extensive social action "Children's Week", which we write about in the following subchapters hereof. Furthermore, short texts regarding the rules of bringing up children were published in daily press ${ }^{22}$. Trends in the childcare were discussed by the PCC's members in its own monthly magazine "Childcare" ("Opieka nad Dzieckiem"), including topics regarding the protection of motherhood and care for youth and children. The magazine included articles regarding, among others: bringing up children, their health as well as physical, intellectual and moral development. Organisation of proper care for the disabled child was described. Moreover, a reader could learn about the activity of the Station of Care for the Mother and the Child (Stacja Opieki nad Matką i Dzieckiem). Various topics regarding care for an abandoned and homeless child were publicised and promoted. Furthermore, the course of summer camps for children and the "Children's Week" were reported in the "Childcare" ("Opieki nad Dzieckiem"). Theories and pedagogical propositions of the following authors were published in the "Childcare" ("Opieka nad Dzieckiem”), among others: J. Czesław Babicki, Cezary Bezerowski, Jan Bogdanowicz, Jerzy Bujalski, Witold Chodźko, Antoni Dobraczyński, Emil Godlewski, Franciszek Gröer, Maria Grzegorzewska, Marceli Gromski, Tomasz Janiszewski, Aleksander Janowski, Stanisław Kopczyński, Janusz Korczak, Wacław Łapiński, Mieczysław Michałowicz, Eugeniusz Piasecki, Helena Radlińska, Maria Weryho - Radziwiłłowiczowa, Maria Roszkowska, Władysław Sterling, Władysław Szenajch, Zofia Szlenkierówna, Tadeusz Szubarowicz, Czesław Wroczyński, Zygmunt Zakrzewski. The aforementioned

20 T. KOPEĆ, Station of Care... (Stacja Opieki...), p. 21.

${ }^{21}$ J. PAWIŃSKA, The meaning of summer camps for children (Znaczenie kolonij letnich dla dzieci), Childcare (Opieka nad Dzieckiem) 1930, no. 3, p. 127.

${ }^{22}$ n.a., Do not beat children. You do not beat out bad inclinations and flaws with a cane, whip or belt (Nie bijcie dzieci. Rózgą, batem i pasem nie przepędza się złych skłonności $i$ wad), Białystok Journal (Dziennik Białostocki) 1928, no. 261. 
surnames of renowned representatives of medical, pedagogical and psychological sciences provide an evidence for the high substantive level of published articles as well as the importance of the Polish Childcare Committee.

\section{The aims and organisational assumptions of the "Children's Week"}

From 1928 to 1938 , initially in Autumn and in the 30 s of the $20^{\text {th }}$ century - in Spring ${ }^{23}$, the Polish Childcare Committee organised the annual "Children's Week" with the principal aim to draw the society's attention to the role of the child in the nation's future as well as to the need for increased care for the youngest citizens of the Second Republic of Poland. Ideas of the "Children's Week" were presented by Mieczysław Jan Michałowicz ${ }^{24}$, a political and social activist, founder of the Paediatric Society (Towarzystwo Pediatryczne), who wrote in the "Childcare" ("Opieka nad Dzieckiem”) as follows:

Children's Week? - of course in May. Happy, smiling children's faces are in harmony with the white-pink flowers in orchards, fair eyes with the blue of the sky in May. Spring and a childan image of cheerful joy undistorted with the life's dirt.

In May, in the Children's Week a child is in the spotlight: it is the most important, adults are less significant.

An adult looks at its Majesty, the Child in its May state and does not recognise the everyday Cinderella.

- Is it the one? The one that only yesterday was obnoxious, disobedient, dirty and annoying?

The Prince wears a sunny outfit made of carefree childishness instead of a grey rug of everyday suffering.

- Which child is more real: the yesterday's or today's, from the May week ${ }^{25}$.

Organisers of the "Children's Week" primarily focused on the ideological meaning which was connected with practical activities in the area of childcare. It was assumed that the "Children's Week" should raise an increased interest among Poles as well as understanding for issues regarding the situation of children and youth. Organisation of the "Children's Week" was intended to demonstrate the importance of taking a loving and proper care of the youngest ${ }^{26}$. For seven days a week the society's attention was drawn to issues related with brining up, education and care for children, who were homeless, ne-

${ }^{23}$ For the first two years "Children's Week" was organised in autumn (16-23.09.1928; 15-22.09.1929), then, it was moved to spring (May 1930; 26-31.05.1931; 1932; 18-25.05.1934; May 1936, 23-30.05.1937; 22-29.05.1938). "Children's Week" was not organised in 1935 due to the national mourning of the death of the Marshal J. Piłsudski.

${ }^{24}$ P. MAJEWSKI, Members of Parliament and Senators of the Republic of Poland 1919-1939. The Biographical Dictionary (Posłowie i Senatorowie Rzeczypospolitej Polskiej 1919-1939. Słownik biograficzny), volume 4 M-P, Warsaw, 2009, p. 149.

${ }^{25}$ M. MICHAŁOWICZ, How? (Jak?), Childcare (Opieka nad Dzieckiem), 1930, no. 3, p. 115.

26 “Children's Week”. Organisational instructions ( "Tydzień Dziecka”. Instrukcje organizacyjne), Warsaw 1928, p. 1. 
glected and forced to hard and untimely work. It was intended not only to present the often times very difficult situation of children and youth, but also to provide the society with knowledge regarding manners and methods of bringing up the young generation, exploit and use their potential. The intention was to ensure the most favourable conditions for physical, intellectual and moral development of children and youth ${ }^{27}$. Whereas, the practical aspect of the organised "Children's Week" comprised obtaining additional funds for further social activity of the Committee.

The Polish Childcare Committee as the initiator prepared a detailed schedule of the "Children's Week", organisational instructions and propaganda materials. Due to the allPoland range, Voivodeship committees were appointed in each Voivodeship office for the period of organisation and duration of the "Children's Week", which where honorarily presided by a Voivode and usually chaired by the Voivode's wife, which was compliant with the social activity of public servants' and other prominent persons' wives at that time.

\section{General Committee of the "Children's Week" PCC}

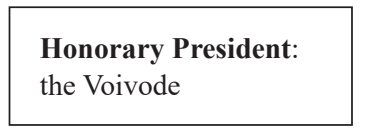

Voivodeship Committees of the "Children's Week" consisted of four sections (organisation of committees, Starost's, propaganda and executory) as well as the audit committee $^{28}$. They dealt with promoting issues regarding childcare in its broadest meaning. Furthermore, they obtained financial and material resources necessary for the operation of particular institutions taking care of children ${ }^{29}$. The task of the Starost's committee organised by Starosts' wives comprised helping with the organisation of Voivodeship committees $^{30}$. The propaganda section dealt with using propaganda materials delivered by the gen-

\footnotetext{
${ }^{27}$ Ibidem, pp. 3-4.

28 „,Children's Week” (“Tydzień Dziecka”)..., pp. 39-40.

29 Ibidem, p. 37.

30 Ibidem, p. 39.
}

Fig. 1. The members of the Voivodeship Committee of the "Children's Week" Dziecka”. Instrukcje organizacyjne), Warsaw 1928, p. 37 
eral executory committee. Additionally, its tasks involved organisation of propaganda lectures and marches as well as including relevant information in local press ${ }^{31}$.

The executory section of the "Children's Week" sold honorary badges, window stickers or stamps especially prepared for the "Children's Week". It also organised local fund-raising in public establishments and private apartments, events of a profit-oriented character as well as negotiated discount sales at commercial and industrial companies ${ }^{32}$. Whereas, the Audit Committee controlled the activity conducted by the executory section and approved accounting statements from Voivodeship committees $^{33}$.

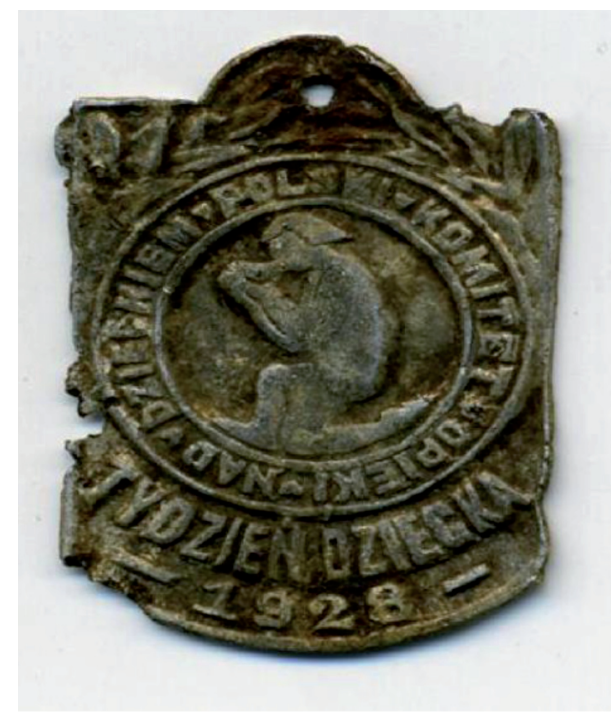

Fig. 2. Medal from the "Children’s Week”, 1928

\section{The course of the "Children's Week"}

The "Children 's Week" in the Second Republic of Poland proceeded according to the schedule that had been drawn up by the Polish Childcare Committee, which was implemented depending on the possibilities of Voivodeship offices and regional conditions in a given Voivodeship. In compliance with the recommendations of the said programme, the first day of the "Children's Week" was the Children's Holiday. The second day was devoted to bringing up a child in its first years of life. The instructions recommended to especially focus on physical education of the child on the third day, on mental education on the fourth day and on moral education on the fifth day. The sixth day was a day on which the attention was paid to children working and gaining vocational education. At the end of the "Children's Week", the seventh day was devoted to a mother, as a woman acting as a pedagogue and working for the greater good ${ }^{34}$.

The Children's Holiday, also described as the Children's Day or the Children's Carnival, was devoted to children aged six to fourteen years old. The prepared day full of

\footnotetext{
31 „Children's Week” (“Tydzień Dziecka”)..., p. 39.

32 Ibidem, pp. 39-40.

${ }^{33}$ LCSA, f. 51, ap. 12, b. 1981.

${ }^{34}$ Ibidem, pp. 4-5.
} 


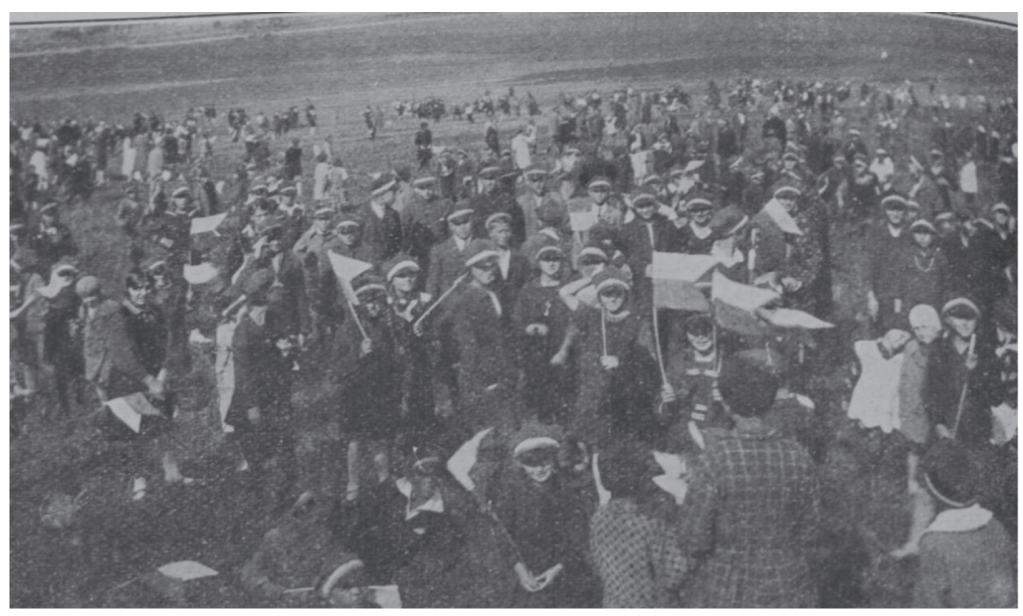

Fig. 3. Children during the march on the Children's Day, carrying white and green flags Source: "Childcare" ("Opieka nad Dzieckiem") 1930, no. 3, p. 145

various attractions was to significantly differ from the everyday reality. During a joyful and full of unforgettable experiences and attractions day no child should stop smiling irrespectively of its difficult situation ${ }^{35}$.

The Children's Holiday started at 8.30 a.m., in schools and preschools children were gathered in order to prepare for participation in the common march. Children received flowers, white and green (PCC's colours) flags and badges and then, with accompanying orchestra walked to a selected spot, where a solemn march started ${ }^{36}$.

In organisational instructions issued by the PCC it was recommended that the children's march did not last longer than one hour and a half and was organised as carefully as possible. In order to improve preparations, pedagogues were informed in due advance of the manner they should form children's marches. Each group of children was given own number informing of its position in the march. Furthermore, pedagogues received information of the route to be covered by children and the ending spot. Places were selected purposefully and they had to have historical value ${ }^{37}$. In Warsaw, in 1930 students participating in the march put flowers at the Adam Mickiewicz's monument, while being accompanied by the national emblem. Then, the march proceeded towards the Royal Castle, where students paid homage to the honorary chairman of the Polish Childcare Committee, Michalina Mościcka, wife of the President Ignacy Mościcki. After the visit at the President's wife, children left to the Tomb of the Unknown Soldier and put flowers there. Then, the march stopped and particular schools dispersed to city parks and gardens

\footnotetext{
35 Ibidem, p. 7.

${ }^{36}$ Ibidem.

${ }^{37}$ „Children's Week” (“Tydzień Dziecka”)..., p. 8.
} 


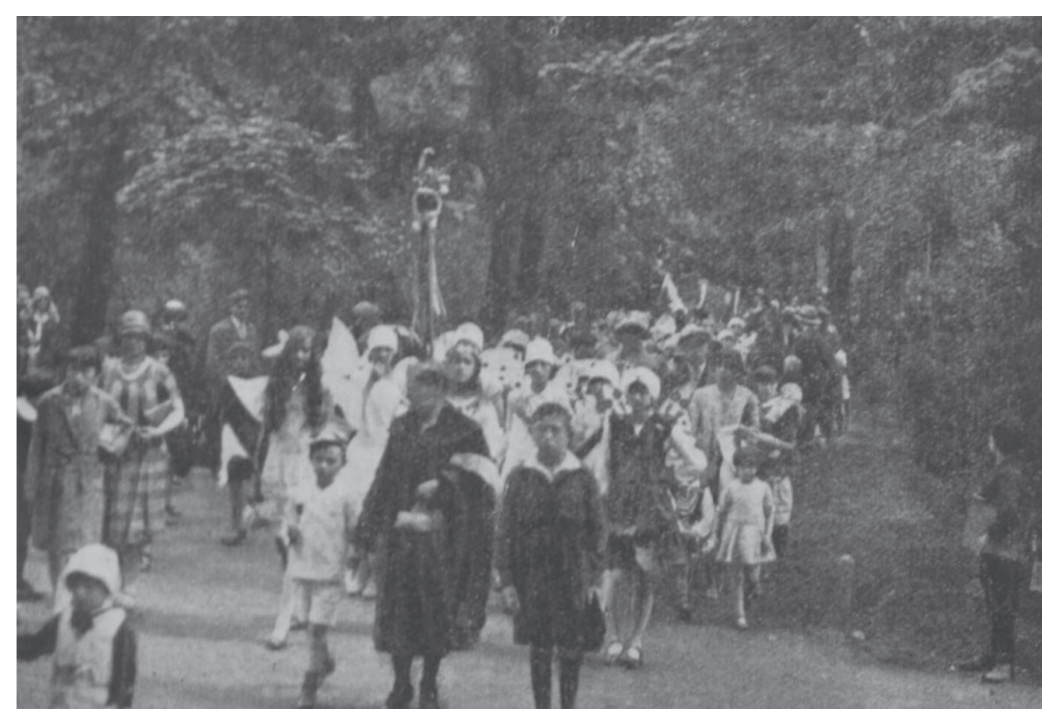

Fig. 4. Children's march in the Saxon Garden, in Warsaw, 1930

Source: "Childcare” ("Opieka nad Dzieckiem”) 1930, no. 6, p. 314

to pass time having fun ${ }^{38}$. After finishing the march at the previously chosen spot, there was a short rest time. Then, children were served a meal consisting of sweet bread, lemonade, milk and sweets and other treats ${ }^{39}$. When the rest time ended and the meal was eaten, children went to theatres and cinemas where they had another attractions in a form of various performances waiting for them. However, those were not random plays. Plays presented to children were happy and cheerful due to the character of the holiday. Participation in initiatives and the possibility to see the performance were surely an unusual attraction giving a lot of joy to many children.

After the dinner break at 4.00 or 5.00 p.m., games in the open air were organised for children attending preschools and younger divisions of elementary schools. The games took place in sports grounds, squares or Doctor's Jordan Gardens (ogrody jordanowskie). In case playing games in the open air was not possible due to weather conditions, they took place in schools' gyms or in factory premises.

The general programme of the Children's Week was a little changed with regard to the youngest children attending preschool. The youngest did not participate in street marches. Instead, trips to neighbouring preschools were organised. During such a trip pre-schoolers

38 National Chronicle. Children's Week in Poland, in 1930 (Kronika krajowa. Tydzień Dziecka w Polsce w 1930 roku), Childcare (Opieka nad Dzieckiem) 1930, no. 6, p. 314.

39 „Children's Week” (“Tydzień Dziecka”)..., p. 8. 


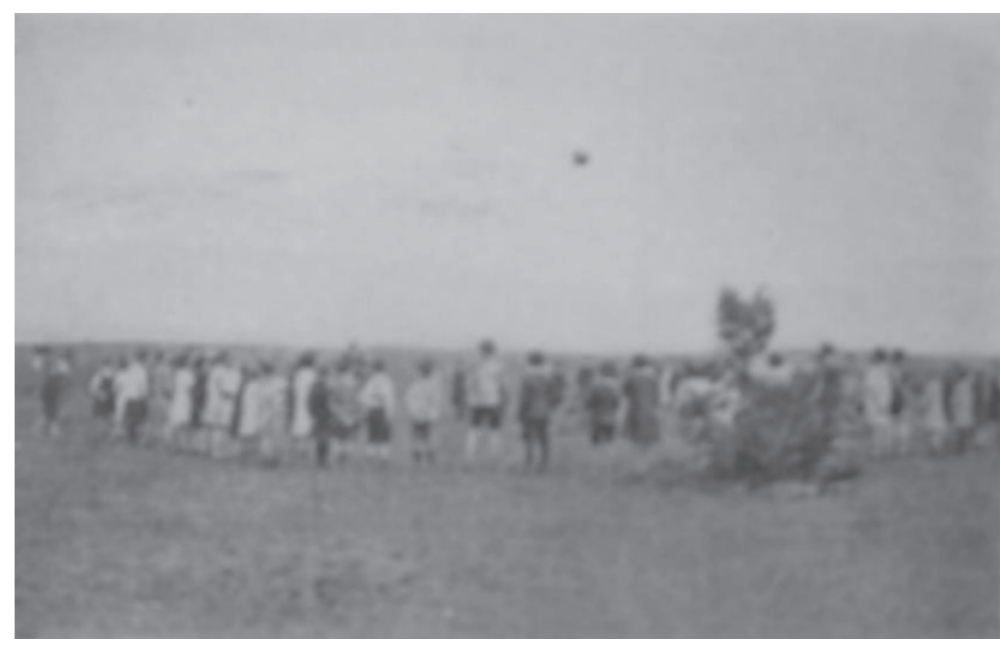

Fig. 5. Children from Warsaw school no. 197 during football match on the Children's Day Source: “Childcare” ("Opieka nad Dzieckiem”) 1930, no. 7, p. 351

carried colourful flags just like their older colleagues. Upon arrival, hosts and guests eat dinner together and passed time on joyful games. At the end of the day each child was given a sweet gift in a form of candies. In Warsaw, in 1930, pre-schoolers, who did not participate in the march, passed time in compliance with the plan prepared by the school inspectorate in one of the city parks: Jordanowski, Ujazdowski, Traugutta, Saski, Skaryszewski etc. Children were playing in parks to the accompaniment of military or police orchestras. Numerous attractions included, among others: a cruise on the Vistula River, performances in cinemas, gymnastics shows in Agrykola ${ }^{40}$.

Despite the framework programme drawn up by the Polish Childcare Committee, while preparing attractions for children organisers of the Children's Week took into consideration the characteristics of a given city/town and regional differences between Voivodeships. Therefore, children living at the seaside could participate in a cruise on the Baltic Sea or took a walk on the Sopot Pier, whereas, children from Southern Voivodeships passed the day on trips in the mountains ${ }^{41}$.

The Children's Holiday was also organised by the minorities, for example: a solemn march of Jewish children in Bialystok, in 1928, where almost half of the citizens were $\mathrm{Jews}^{42}$. Over four hundred students from private Jewish schools together with their teach-

40 National Chronicle. Children's Week in Poland, in 1930 (Kronika krajowa. Tydzień Dziecka w Polsce w 1930 roku), Childcare (Opieka nad Dzieckiem) 1930, no. 6, pp. 314-316.

${ }^{41}$ National Chronicle... (Kronika...), 1930, no. 7, pp. 538-539.

42 Białystok had multi-ethnical and multi-religious structure. In 1919, the city was inhabited by Jews (53.7\%), Catholics (40.2\%), Evangelicals (3.25) and Orthodox (2.8\%). See A. LECHOWSKI, Biatystok in the years 1919-1939 (Biatystok w latach 1919-1939), [in:] The History of Biatystok (Historia Biategostoku), A.Cz. DOBROŃSKI (ed.), Białystok 2012, p. 367; A. SADOWSKI, Biatystok as a type of an ethnically diverse city (Białystok jako typ miasta zróżnicowanego etnicznie), [in:] Białystok in the 80s. On the anniversary of 


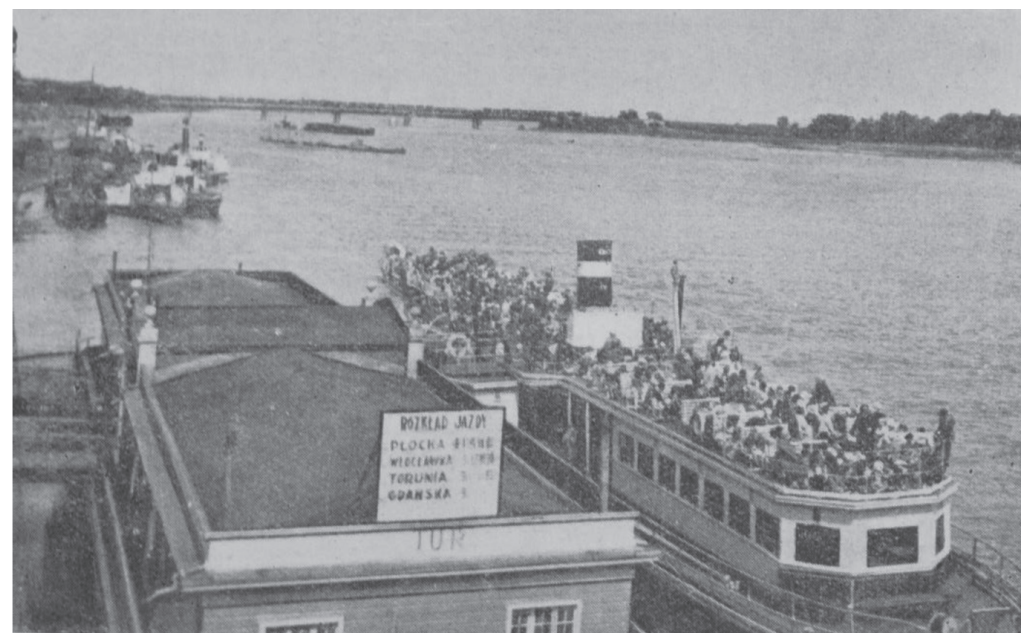

Fig, 6. Cruise on the Vistula River organised in the Children's Week, Warsaw 1930 Source: "Childcare" ("Opieka nad Dzieckiem") 1930, no. 6, p. 315

ers marched to the market square Rynek Kościuszki, where a parade took place, among others: before the President of the city, colonel Michał Ostrowski, the Voivode's wife Maria Kirstowa, the Deputy Voivode, the President of the Treasury Office, the Head of the Self-government Department, the Starost, the Police Voivodeship Commissioner and the School Inspector Mieczysław Jurecki ${ }^{43}$.

The second day of the "Children's Week" was the time where attention was paid mainly to the issues related with bringing up children in the first years of their age. On that day, an attempt was made to equip parents and pedagogues with the newest knowledge regarding, among others: care for an infant and a child up to three years old, bringing up and hygiene. Citizens were recommended to visit the Stations of Care for the Mother and the Child (Stacje Opieki nad Matką i Dzieckiem), nurseries, formation houses and to learn about the activity of the action: A Drop of Milk (Kropla Mleka) ${ }^{44}$.

On the third day, as that day was devoted to physical education, it was recommended that the society paid attention to the conditions of local camps, semi-camps, gyms and sports clubs. On that day, youth's gymnastics shows were prepared, which was aimed at encouraging physical activity and constituted the best form of propagating physical education $^{45}$.

regaining independence 19 February 1919 - 19 February 1999 (Białystok w 80-leciu. W rocznice odzyskania niepodległości 19 luty 1919 - 19 luty 1999), C. KUKLO (ed.), Białystok 2000, p. 182.

${ }^{43}$ Children’s Holiday (Święto Dziecka), Białystok Journal (Dziennik Białostocki) 1928, no. 262.

${ }_{44}$ A Drop of Milk (Kropla Mleka) was an organisation delivering ready-made milk mixtures for infants in a situation, when a mother did not have own milk or could not breastfeed for some reason.

45 „,Children's Week” (“Tydzień Dziecka”)..., p. 12. 


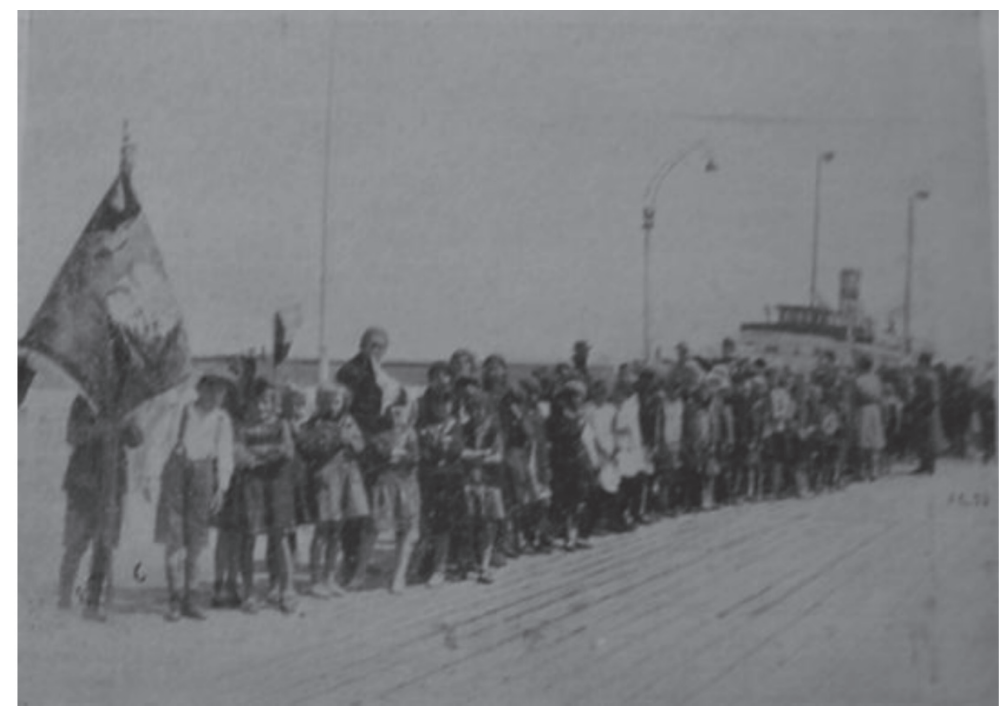

Fig. 7. Children on the Sopot Pier

Source: “Childcare” (“Opieka nad Dzieckiem”) 1930, no. 7, p. 538

The doors of preschools and schools were opened on the fourth day of the Children's Week. Prominent persons from a given city/town were invited to school establishments, where students prepared exhibitions of their works. Moreover, various lectures were organised aimed at explaining the reason for operating particular educational establishments and institutions. It was aimed at contributing to the society's increased interest in those establishments and at positively influencing cooperation of pedagogues and parents. The Polish Childcare Committee also recommended visiting establishments for children with intellectual disability, and in case such an establishment was not present in a given city/ town, then Voivodeship committees recommended special education experts to have a lecture on the subjective treatment of disabled children ${ }^{46}$.

Whereas, the fifth day was devoted to issues related with moral education, therefore, the society was recommended to visit educational establishments, which aim was to counteract adverse impact of the environment on children and youth. A special attention was paid to meet spiritual needs of the young generation, inducing the longing for what is good ${ }^{47}$. The youth themselves were engaged in the organisation of that day and they provided a lot of information to persons visiting particular establishments. Visiting those establishments surely influenced the increase in initiatives and interest in matters regarding youth and children and in particular, the matters regarding their moral education. Through the agency of such activities it was intended to lower the level of juvenile delinquency and thus, eliminate the results of educational negligence during partitions and the

\footnotetext{
46 Ibidem, pp. 12-13.

47 „Children's Week” (“Tydzień Dziecka”)..., pp. 13-14.
} 
First World War. Therefore, taking care of the moral development of children and youth was in a way treated as civil obligation of each Pole, who cares for the homeland's fate ${ }^{48}$. Establishments for semi-orphans and orphaned children were mainly visited. A particular attention was paid to the meaning and role of those establishments in the process of bringing up abandoned and educationally neglected children. The Committee wanted to raise the society's interest in those establishments as well as to encourage taking care of all children. At that time, the idea of so-called: circles of carers arose, which assumed that people were to take an orphan or a semi-orphan home for Sundays and holidays. This initiative was intended to ensure a possibility of spending time in family atmosphere, which was especially pleasant for a young person staying at an orphanage or other educational establishment ${ }^{49}$.

On the last but one day of the "Children's Week" the society paid attention to children working and attending vocational schools. On that day establishments employing minors were visited. It was also an occasion to acquaint gathered audience with the legislation binding in the territory of the Second Republic of Poland as well as the types and conditions of work performed by minors. Furthermore, on that day the importance of vocational education of youth graduating school was underlined ${ }^{50}$.

The last, seventh day of the "Children's Week" was devoted to a mother, who was attributed with the most important function with regard to upbringing. The Polish Childcare Committee even drew up a detailed schedule, which stipulated how that day should proceed, what kind of events should be organised ${ }^{51}$. A solemn Mother's Day started in the afternoon hours with lectures and talks devoted to the issues concerning the obligations and rights of a woman - mother pursuant to the legislation on the social protection and care, in the context of the activity of advice offices for pregnant women and Stations of Care (Stacje Opieki) as well as the situation of a working mother being the only breadwinner for their children. Another issue discussed during lectures organised for mothers comprised their role as "spiritual leaders" in the child's moral education. On the Mother's Day, social carers, who were supporting mothers in motherhood and in the case of orphans even replaced them, were not forgotten. During Mother's Day preparations the General Organisation Committee (Naczelny Komitet Organizacyjny) encouraged Voivodeship committees to appoint societies helping and supporting mothers in their motherhood. During lectures, pedagogical leaflets and publications including educational guidelines were distributed. In the evening, cinemas and theatres prepared repertoire with a consideration of women's preferences ${ }^{52}$. On 29 May 1930 municipal preschools in Warsaw organised the Mother's Holiday which fell on the celebration day of the Assumption of Mary into Heaven. Therefore, almost all mothers of pre-schoolers as well as many fathers were

\footnotetext{
48 Ibidem, pp. 14-15.

49 Ibidem, pp. 15-16.

50 Ibidem, pp. 16-17.

51 Ibidem, pp. 17-18.

52 Ibidem, pp. 17-18.
} 


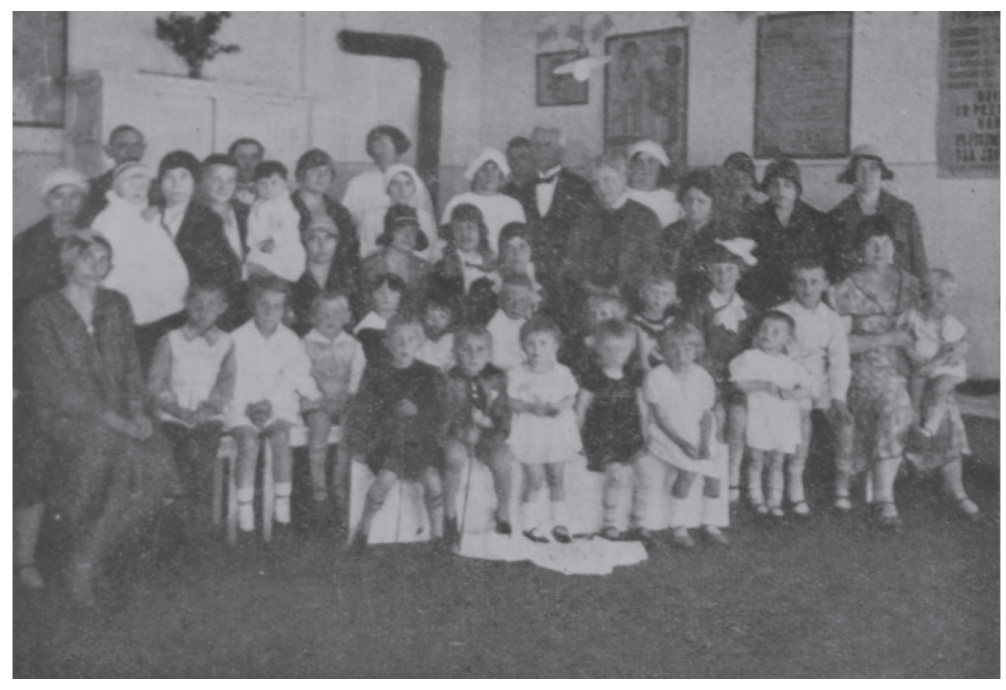

Fic. 8. Mothers awarded in 1929 on the occasion of the "Children's Week" in the Station for Care of the Child (Stacja Opieki nad Dzieckiem) of the PCC, Warsaw ul. Podwale 50

Source: "Childcare” ("Opieka nad Dzieckiem") 1930, no. 6, p. 315

present on the Holiday. Pre-schoolers prepared an artistic part for their mums - they recited poems, sang songs and danced. Each mother received from her child flowers and a booklet entitled: To Mother! (Tobie Matko!) ${ }^{53}$. The pedagogues made occasional speeches. The Mother's Holiday also comprised an occasion for parents to learn about the year's work of their children, which was presented at local exhibitions especially prepared for this purpose ${ }^{54}$. Furthermore, the Mother's Day was an occasion for the PCC to award mothers with a model conduct, who contributed to the Committee's social actions.

\section{Social meaning of the "Children's Week"}

The "Children's Week" was an event of an immense importance for the society. During these few days a year, the society's attention, which might have been lacking in everyday life, was focused on issues related with taking care of a child. The action was of an explicitly propaganda character; it made the society aware of the role and meaning of a child in the nation's future and induced the sense of responsibility for taking care of the young generation, thus, establishing a social attitude. As the slogans should be followed by actions, the Polish Childcare Committee hoped that new societies would be established, whose task would be to take care of all children, healthy and sick, disabled, neglected and

\footnotetext{
53 To Mother! (Tobie Matko!), Warsaw 1931.

${ }^{54}$ National Chronicle. Children's Week in Poland, in 1930 (Kronika krajowa. Tydzień Dziecka w Polsce w 1930 roku), Childcare (Opieka nad Dzieckiem) 1930, no. 6, p. 316.
} 
abandoned $^{55}$. It also influenced establishing cooperation between people who were not indifferent to the fate and wellbeing of a child ${ }^{56}$.

Furthermore, the "Children's Week" provided a possibility to obtain funds to execute activities of the Polish Childcare Committee. Collected money was used to organise summer camps, conduct Stations of Care for the Mother and the Child (Stacje Opieki nad Matką i Dzieckiem) or A Drop of Milk's (Kropla Mleka) actions ${ }^{57}$.

A very important issue comprised noticing the importance of the necessity to pay more attention to children. Enabling the child to develop in an unlimited manner and grow up with self-confidence in accordance with idea of the "Children's Week", which was compliant with the European tendencies of that time, where rights and freedoms of a child were gathering an increasingly large group of supporters.

The idea and organisation of the "Children's Week" was also criticised a lot. Opponents believed that too much funds are allocated to the propaganda action, issuing occasional bulletins and publications instead of investing this money in implementing specific tasks in the scope of childcare. The authorities of the Polish Childcare Committee did not give in to those critical comments and stood on the position that the aware society naturally supports social activities and, as a consequence, such activities intensify. The organisation of the "Children's Week" engaged representatives of the aristocracy, intelligentsia as well as owners of factories, stores and confectioneries. Furthermore, organisation of the Children's Week was supported by pedagogy and medicine experts. Janusz Korczak wrote about the "Children's Holiday" in the "Childcare" ("Opieka nad Dzieckiem"): It is not a church or public holiday, but a nice, cheerful day of rest, playing games and giving gifts to children (...) This is a holiday of reconciliation, a holiday of coalition. To forgive those who wronged us, to forget regrets, to promise mutual, forgiving friendship ${ }^{58}$. Whereas, Józef Czesław Babicki claimed that during the "Children's Week" children are more natural and authentic, because the sense of self-worth allows them to be themselves. An adult is less important and a humble sense of own inferiority allows them to notice the child ${ }^{59}$.

During the "Children's Week" children's needs with regard to being healthy, wise, kind and happy were discussed. Whereas, the activity of the Polish Childcare Committee arose from the Geneva Declaration of 1924, which was the first common legal act to underline the child's right to physical, intellectual and emotional development and indicated adults' obligations towards children. The celebration took place in the interwar period only in Poland, Greece and Turkey. This can prove the difficult situation of a child and urgent need to educate the society as well as our "falling behind" with regard to the European pedagog-

${ }^{55}$ M. MICHAŁOWICZ, How? (Jak?), Childcare (Opieka nad Dzieckiem), 1930, no. 3, p. 115.

56 Ibidem, p. 115.

57 J. PAWIŃSKA, The meaning of summer camps for children (Znaczenie kolonij letnich dla dzieci), Childcare (Opieka nad Dzieckiem) 1930, no. 3, p. 129.

58 J. KORCZAK, Children's Holiday (Święto Dzieci), Childcare (Opieka nad Dzieckiem) 1930, no. 3, p. 120.

59 J.Cz. BABICKI, Will they learn to laugh? (Czy śmiać się nauczą?), Childcare (Opieka nad Dzieckiem) 1930 , no. 3 , p. 135. 
ical trends. And maybe this is an evidence of the systemic functioning of the social care for the child and an example of innovative direction in the pedagogy of the Second Republic of Poland? The more so, the activity of the Polish Childcare Committee, the organisation which developed the system of care-related activity in the whole Poland, deserves to be studied more deeply. Whereas, engaging persons from the group of the highest civil servants in the organisation of the "Children's Week" provides an evidence of mutual direction of social activity understood as the need to help others and especially, children. Moreover, the "Child's and Mother's Holiday" can be seen as the genesis of contemporary holidays celebrated on 26 May (Mother's Day) and 1 June (Children's Day). Ironically, before the war, those holidays were grouped as the "Children's Week" and this dualistic combination demonstrated mutual relation between a child and a mother and the separation of those days after the Second World War at the same time symbolically divides and atomises this relation. Following this direction, one can reach another meander of contemporary pedagogy. If, soon after the partition period and the First World War, in order to provide help and induce social attitude, the Polish Childcare Committee within many forms of its activity organised annually the "Children's Week", as an educating action, then, in the $21^{\text {st }}$ century do we have to be more aware of the children's needs and are we able to provide them with freedom and safety, since the "Children's Day" lasts only one day? Let us leave the answer to this question implicit or let it be found in the glorious history of the Polish pedagogical thought and practice.

\section{Bibliography}

\section{Source materials}

Vilnius, the Lithuanian Central State Archive (LCSA), f. 51, ap. 12, b. 1981.

KOPEĆ T., Stacja Opieki nad Matka i Dzieckiem, in the series: "Zagadnienia opieki nad macierzyństwem, dziećmi i młodzieżą w Polsce”, Warsaw 1932.

Statut Polskiego Komitetu Opieki nad Dzieckiem, Warsaw 1926-1928.

Tobie Matko!, Warsaw 1931.

Tydzień Dziecka. Instrukcje organizacyjne, Warsaw 1928.

\section{Press}

"Dziennik Białostocki" 1928-1939.

“Opieka nad Dzieckiem” 1923-1931.

“Życie Dziecka. Czasopismo poświęcone ochronie macierzyństwa, opiece nad dziećmi i młodzieżą” 1932-1937.

“Życie Młodych. Czasopismo poświęcone ochronie macierzyństwa, opiece nad dziećmi i młodzieżą" 1938-1939. 


\section{Scientific works}

LECHOWSKI A., Białystok w latach 1919 - 1939, [in:] Historia Białegostoku, DOBROŃSKI A.Cz. (ed.), Białystok 2012.

MAJEWSKI P., Posłowie i Senatorowie Rzeczypospolitej Polskiej 1919-1939. Stownik biograficzny, $4^{\text {th }}$ volume M-P, Warsaw, 2009.

OSMAŃCZYK E.J., Encyklopedia ONZ i stosunków międzynarodowych, Warsaw 1982.

RYBARCZYK G., Amerykańska pomoc dla dzieci polskich po I wojnie światowej oraz inne formy pomocy w latach 1919-1923, Biuletyn informacji bibliotecznych i kulturalnych 2005, no. 1.

SADOWSKI A., Białystok jako typ miasta zróżnicowanego etnicznie, [in:] Biatystok w 80 - leciu. W rocznicę odzyskania niepodległości 19 luty 1919 - 19 luty 1999, KUKLO C. (ed.), Białystok 2000.

WRÓBLEWSKA U., “Tydzień Dziecka” - idea korczakowska w międzywojennym Biatymstoku, [in:] KRYŃSKA E.J., SUPLICKA A., WRÓBLEWSKA U., (ed.), Dziecko w historii-watek korczakowski, Białystok 2013.

WRÓBLEWSKA U., Tydzień Dziecka? - inspiracje korczakowskie dzisiaj, A. KORZENIECKA-BONDAR, B. TOŁWIŃSKA, U. WRÓBLEWSKA (ed.), Światy życia codziennego uczestników interakcji wychowawczych Eksploracje - Analizy - Interpretacje, Zeszyty naukowe Forum Młodych Pedagogów, 2012 bulletin no. 17. 
